\title{
Financial Capability and Asset Building: A Transformational Practice Framework
}

\author{
Edward Scanlon \\ Cynthia K. Sanders
}

\begin{abstract}
The promotion of financial capability and asset building (FCAB) is an important and fitting professional activity for social work, which has long been concerned with the economic well-being of individuals and families. Financial capability is attainable only if we assist clients by helping them to build new skills while simultaneously helping them to connect to economic opportunity structures such as savings, job training, or credit repair programs. We propose a person-environment-centered process model for use in FCAB endeavors, using case vignettes to illustrate the application of the process. By drawing upon several theoretical perspectives such as humanistic social work, cognitive behavioral theory, motivational interviewing, solution-focused brief therapy, and diffusion of innovations theory, practitioners may increase clients' likelihood of successfully connecting to opportunity structures. Attention to behavioral, cognitive, emotional, and policy feedback processes may help to provide the "missing link" between individual financial behavior and the institutional opportunities offered by FCAB programs.
\end{abstract}

Keywords: Financial capability; direct practice; financial literacy; person-environment practice; economic well-being

The promotion of financial capability and asset building (FCAB) is an important and fitting professional activity for social work, which has long been concerned with the economic well-being of individuals and families. Because financial capability has been conceptualized as the result of the interaction of human agency (the ability to act) with social structures (institutions which create the opportunity to act), it is congruent with social work's emphasis on person-environment practice (Birkenmaier, Sherraden, \& Curley, 2013; Johnson \& Sherraden, 2007; Kemp, Whittaker, \& Tracy, 1997).

However, theoretical perspectives in the financial capability field and the asset building field have been conceptualized in relative isolation from one another. Financial capability has relied more heavily upon an individualistic view of economic actors, and focuses upon helping individuals to learn new skills, knowledge, and practices, often ignoring clients' social and economic contexts. Those working to help individuals gain financial knowledge have relied upon individually-focused interventions such as financial education (Collins \& O’Rourke, 2009) and financial therapy (Archuleta \& Grable, 2011). Conversely, the asset building field, which helps individuals and families to accumulate wealth through savings or investment (Sherraden, 1991), has focused more on structural theories, such as asset theory and behavioral economics, and has had relatively little to say about micro-level skills or theories (Despard \& Chowa, 2010; Sherraden, Laux, \& Kaufman, 2007). We believe that the theoretical differences between these two elements of the FCAB field have

Edward Scanlon is Associate Professor and Associate Dean for Academic Programs, School of Social Welfare, University of Kansas, Lawrence, KS 66045. Cynthia K. Sanders, PhD, Professor, School of Social Work, Boise State University, Boise, ID. 
led to a lack of role clarity on the part of agency level staff tasked with the delivery of these programs.

It is important for social work to incorporate both structural and individual factors in our understanding of financial capability. Failing to incorporate a structural view of FCAB can lead to a sort of victim-blaming in which individuals are assigned responsibility for their financial circumstances without acknowledgement of the social, political, and economic systems that shape financial life chances (Olen, 2012). At the same time, while structural theories are appropriate frameworks for constructing social policy and programs, they are less useful as a guide for direct practitioners who contend with the complicated dynamics of human behavior and interpersonal interaction. While the specific structural changes needed for a fully inclusive and just financial system are beyond the scope of this paper, working directly with clients to promote financial capability requires an understanding of the political and economic environments in which clients live, and it requires an understanding of relevant psychological and behavioral characteristics that impact outcomes.

In this article, we present a theoretically-driven, person-environment framework for FCAB practice. We suggest a model for use by social workers practicing in settings that focus on promoting financial well-being, such as Individual Development Account (IDA) programs, low-income housing-based services, financial self-sufficiency, and employment or job training programs. We propose a five-stage process model for FCAB, illustrated by several case vignettes. By drawing upon insights from several theoretical perspectives, such as humanistic social work, cognitive behavioral theory, motivational interviewing, solution-focused approaches, and diffusion of innovations theory, practitioners may be able to assist clients in a more thoughtful and purposeful way. Attention to behavioral, cognitive, emotional, and policy feedback processes may provide the missing link between individual financial behavior and the institutional opportunities offered by FCAB programs.

\section{Ontological Assumptions in the Social Sciences: Holism, Methodological Individualism, and Critical Realism}

Before we suggest some basic elements of a direct practice model, it is important to note that the practice of financial capability and asset building raises critical questions about the nature of social reality, particularly the ways in which individuals and society are conceptualized. Within the discipline of philosophy, ontology is the study of the nature of being, and is also concerned with how things which exist relate to one another (Blaikie, 1993). Debates exist in the philosophy of social science that center on the ways in which society is conceptualized, particularly in terms of differing views of the relationship between social structure and human agency. Two dominant perspectives in the social and behavioral sciences are 1) holism, and 2) methodological individualism (Zahle \& Collin, 2014).

Those whose ontology is grounded in holism contend that social institutions and forces shape human behavior and the opportunities and choices that are available to individuals. In this view, social structures precede individual action, and social forces and institutions 
are themselves the proper unit of analysis for understanding human behavior (Blau, 1977). Conversely, methodological individualists focus on the idea that human beings are free agents who make rational decisions, and see society as the sum of the choices and behaviors of vast numbers of individual actors. Individual behavior is viewed as the appropriate unit of analysis, and individual choices and decisions precede social structures. This ontological perspective can be seen in the assumptions of neo-classical economics and in certain social science perspectives such as rational choice theory and the theory of planned behavior (Kjosavic, 2003).

A critical realist view of the relationship between structure and agency suggests a different perspective. Philosopher Bhaskar's (1975) transformational model of social action posits that individuals live within, and are impacted by, social structural arrangements, but they are also capable of responding to, and altering, those structural forces. Similar dialectical views of reality can be found in the work of scholars such as Giddens (1984) and Bourdieu (1980), who also focus on the interactions of social structures and individual agency. Referring to this as structuration theory, Giddens (1984) suggested that structures exist and allow the reproduction of society across space and time. Individuals experience these structures as trace memories and also work in various ways to transform those structures. In that process, they themselves are transformed. In Giddens' view, society is like a wall made up of bricks which are continually reconstituting themselves. Giddens rejects the notion of duality, and the idea that structure and agency are separate processes. Instead, as it is for Bhaskar, this process is transformational in the sense that society and individuals are constantly recreating one another, mutually altering each other's properties and structures. Similar views can be seen in the French sociologist Bourdieu's (1980) conceptualization of social life, with his emphasis upon constructs of field and habitus.

\section{Financial Capability and Asset Building as a Transformational Social Process}

Among the helping professions, a unique contribution of social work has been its emphasis upon viewing clients and their environments simultaneously. The personenvironment perspective is built upon an assumption that neither methodological individualism nor holism is fully capable of explaining human functioning. Rather, social work has staked out a position which is compatible with that of Bhaskar (1975), Giddens (1984) and Bourdieu (1980) — the notion that structure and agency are dialectically-related. Our professional commitment is to intervene simultaneously with social environments and with individuals and to work to ensure a goodness-of-fit between the two (Germaine \& Gitterman, 1980; Meyer, 1983). This is, in essence, a transformational view of human nature.

Financial capability theory begins with similar assumptions about human nature. The idea of financial capability is based upon an implicit critique of the methodological individualism embedded in traditional financial education training. The traditional approach to financial education has assumed that individuals can receive education about financial issues (i.e., banking, credit cards, investing), and then, once exposed to essential knowledge, will begin to behave in ways that are financially logical, goal-directed, and sound. Johnson and Sherraden (2007) and Birkenmaier and colleagues (2013) offer a more 
sophisticated approach by suggesting that individuals will not develop financial capability simply through gaining knowledge. Instead, they suggest financial capability requires financial inclusion; individuals must be connected to institutional structures which provide them with the opportunity to save, use credit, and invest. When financial education is combined with financial inclusion, financial capability can be built.

In our view, the financial capability approach is truly a person-environment perspective which links social structures and human agency. And what is more, this view is compatible with a critical realist view; financial capability, as conceptualized, appears to be what Bhaskar (1975) refers to as an emergent property, which is a new social entity that is more than the sum of its parts. In other words, as opportunity structures (incentivized savings, credit access) interact with financial education and new financial experiences for individuals, a new social property (financial capability) is created. And, as more financial capability is built, it is plausible that individuals will be even more likely to successfully access structural opportunities such as asset-building programs, promoting the virtuous cycle which Sherraden (1991) hypothesized about in the early asset-building literature.

\section{Linking Individuals and Opportunity Structures: A Focus on Process}

The central task of FCAB social work should be to connect clients successfully to opportunity structures that may improve their financial well-being. These opportunity structures, such as employment, savings, fair credit, and job training, facilitate individual and family well-being. In the FCAB context, Beverly and Sherraden (1999) have suggested that institutional features of asset building programs are largely responsible for promoting the accumulation of wealth. On the other side of the person-environment configuration, we propose that there are also individual facilitators (which are behavioral or psychological in nature) that promote FCAB. There is precedence for this view. In their model of determinants of asset building, Beverly and colleagues (2008) acknowledge the relevance of individual factors, including three psychological variables: future orientation, motives for saving, and perceived ability to save. We suggest that additional individual-level psychological and behavioral characteristics may also promote financial capability (see Figure 1, including: 1) trust (a belief that an FCAB program is honest, reliable and effective), 2) engagement (feeling attracted to, and willing to participate in, FCAB activities), 3) commitment (an authentic agreement to work to achieve financial goals), 4) financial problem-solving skills (cognitive and behavioral skills that can be used to help achieve FCAB goals), 5) perseverance (continued effort at FCAB activities despite facing short-term setbacks or obstacles), and 6) self-reflection and abstract thinking (awareness about one's own financial behaviors and the ability to apply FCAB knowledge to different financial circumstances). 
Figure 1: Psychological and Behavioral Characteristics Which Facilitate the Use of Financial Capability and Asset Building Programs

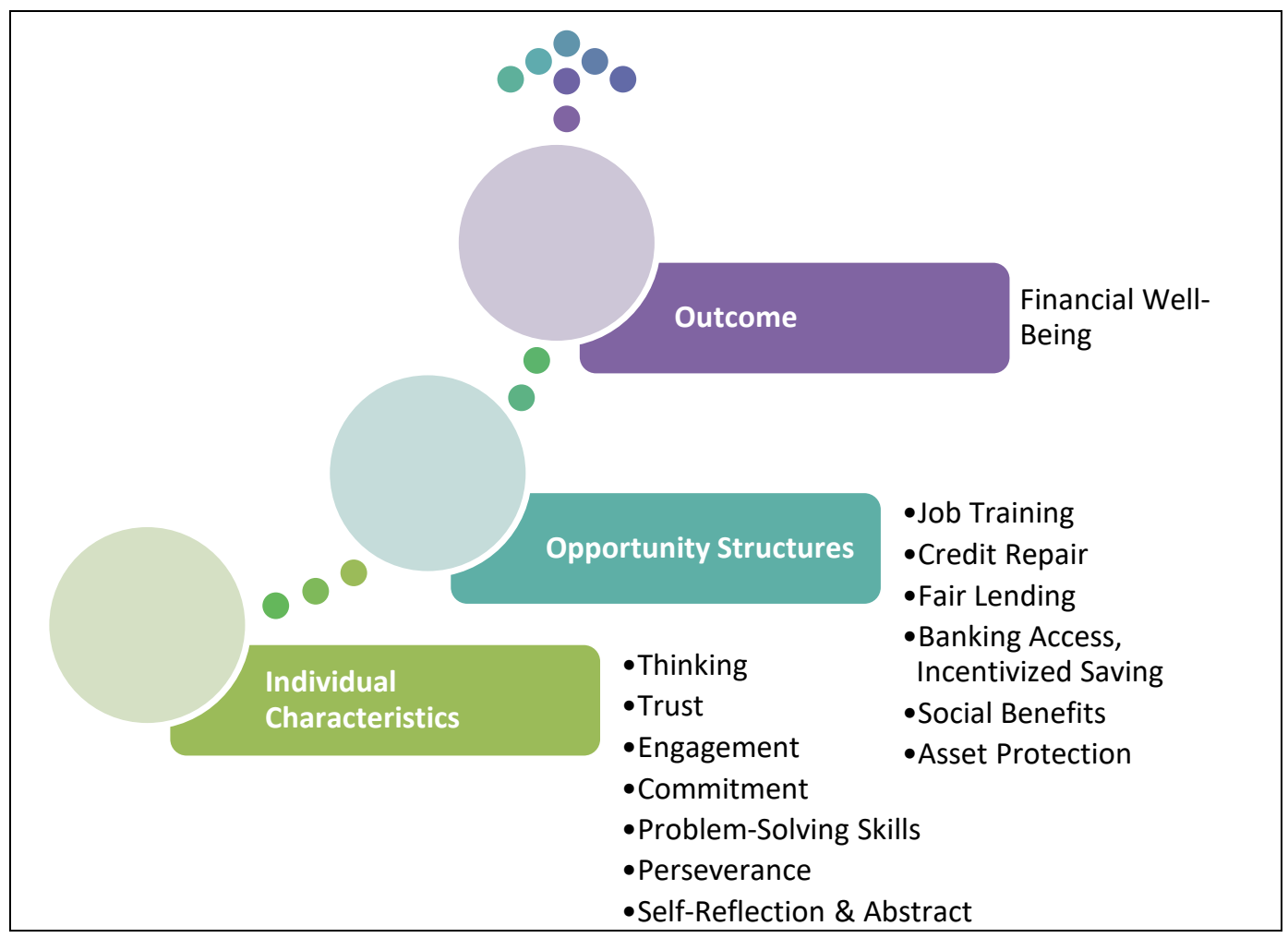

A focus in direct practice in FCAB should be helping individual clients to develop these behaviors and attitudes so that they may more effectively link to opportunity structures. Providing linkages to services is a "tried and true" social work role described in basic social work practice texts; it has long been considered to be one of the core roles of the professional social worker (Kirst-Ashman \& Hull, 2011). Some theorists have even argued that social work is boundary work intervening in the transactions that occur between individuals and social, economic, cultural, and political structures across various stages of the life span (Germaine \& Gitterman, 1980). But doing successful boundary workeffectively connecting clients to services and programs-requires the thoughtful application of theory and skills. We cannot simply refer clients to services, or provide them with information about program availability, and assume successful outcomes will follow. Instead, social workers must encourage this linkage to opportunity structures, and purposively engage in a helping process that facilitates trust, engagement, commitment, perseverance, problem-solving, and self-reflection. We posit that those factors, successfully developed and enhanced, may increase the likelihood of successful boundary work. At the same time, direct practice FCAB workers must still consider ways of impacting and shaping those opportunity structures so that they are accessible, safe, and non-exploitative, particularly for financially vulnerable populations. 
Social workers in direct practice can use practice theories and skills to help clients to cultivate and develop these qualities. We again refer to Bhaskar's (1975) insights, suggesting that these qualities are not simply inherent in some individuals - rather they are, at least in part, emergent properties that can arise through positive and purposeful interactions between direct practitioners and consumers. Helping these qualities emerge may best be achieved through a deliberative FCAB practice process model which moves through stages parallel to those typically included in a generalist model of social work practice (Kirst-Ashman \& Hull, 2011). We view this as a five-phase process which includes: 1) rapport building and engagement, 2) securing goal commitment, 3) overcoming obstacles and developing financial strategies, 4) celebrating and reflecting on goal attainment and future ambitions, and 5) evaluating practice and diffusing knowledge. To successfully navigate each phase of the framework, practitioners may draw from different models of practice. In the following section, we describe the theories most appropriate for each phase. Table 1 is included as a graphic depiction of these stages and the related practice theories that we view as most promising for utilization by practitioners.

\section{Rapport-Building and Engagement}

In any process in which a social worker and a client work together to achieve a goal, little can be accomplished unless rapport is built. The goal of this initial phase is to increase the client's trust in the program and the worker, and to begin the process of establishing a sense of engagement in the FCAB process. Building trust is essential; previous research on asset building programs has demonstrated that participating with an agency that is trusted throughout the community is key for the process of recruiting participants (Shanks, Nicoll, \& Johnson, 2014). Similarly, key staff members who are able to foster a sense of trust and build rapport with clients can be extraordinarily helpful in linking clients to FCAB programs and policies (Scanlon \& Wittman, 2010).

Rapport-building has long been viewed as a core element of the social work helping process, with roots in the writings of the professions' pioneers. Relationship as a key to change was an idea that was deeply embedded in the work of scholars such as Taft and Robinson, whose Functional School thinking influenced numerous social work approaches that followed (Ehrenreich, 1985). The concept is compatible with the views of humanistic social work (Payne, 2011), which is based in part upon Roger's (1961) notion that genuineness, warmth, and empathy are the building blocks of change. As social workers begin work with clients, conveying warmth (a general sense of positive regard for the client), authenticity (sincerity and a natural sense of self) and accurate empathy (accurately understanding the thoughts, feelings, and meanings of another person) helps clients to feel supported, listened to, and treated with respect and in a non-judgmental way. Attention to these common factors of change in working with financial consumers has previously been suggested by Despard and Chowa (2010) and by Johnson and Sherraden (2007).

Social workers at this stage would also be wise to draw upon open-ended questions to help clients' stories unfold, particularly those stories which relate to client's relationships with education and training, money, spending, bill-paying, saving, investment, paying taxes, and so forth. Knowledge of clients' financial struggles and successes, for example, could help the worker to understand the client's concerns, values, and motivations for 
participation in FCAB. Providing clients with clear, honest, and effective feedback, and providing them with the information they need in a timely and efficient manner, will go a long way toward developing trust and promoting engagement. Motivational interviewing scholars, for example, emphasize that sharing information in a clear and collaborative manner helps to build relationships because the clinician avoids a condescending expert tone, instead helping the client to identify information that is most helpful to them (Rollnick, Miller, \& Butler, 2008). Congruency between what workers believe and the information that they provide to clients is also key to building trust.

Generating trust, then, depends upon a social worker's ability to provide clients with honest and accurate information about financial products and institutions. An important competency for social workers to demonstrate at this phase is a clear understanding about the risks and benefits associated with financial services. Social workers should have knowledge and information that helps them to educate clients about financial products, including those that are predatory in nature, or are otherwise a poor fit for their financial objectives (Collins \& Birkenmaier, 2013). Helping clients choose the best FCAB opportunities that match their goals, and highlighting those products that have been vetted as secure and non-exploitative of consumers, are essential activities for generating trust. Through such rapport-building activities, the linking properties of trust and engagement can begin to solidify, helping clients to be more receptive to learning about FCAB opportunities which may be available to them. An example follows:

Case Example: Building Rapport with Jeannine. Jeannine is a 36-year-old woman who has two children, Amy, 16, and Darrell, 12. Jeannine has recently graduated from a welfare-to-work program, and has begun working as a certified medical technician. Jeannine has struggled financially throughout her adult life, and was raised in a household by a single mother who also faced chronic difficulties in making ends meet. Jeannine is now working at her first full-time job with benefits, and is extraordinarily proud of what she has accomplished. Despite her newfound success, Jeannine has trouble with budgeting, and with saving money. She also is aware that she has a poor credit rating, and was recently turned down for a credit card.. She has been referred to the Financial Opportunity Center by a former academic advisor from her community college Certified Nursing Assistant program. As she begins the intake process, she becomes quiet and somewhat evasive.

Lourdes, Jeannine's social worker and financial coach, senses Jeannine's hesitancy, and is aware that Jeannine is not verbalizing her concerns. Lourdes again explains the role of the financial coach, and reiterates the importance of confidentiality and the steps that the Financial Opportunity Center takes to ensure the privacy of confidential information. Lourdes uses exploration skills to see if this information is helpful to Jeannine, who replies that it does ease some of her concerns. The social worker then uses reflective listening skills to gently suggest that Jeannine still seems uneasy. Jeannine explains that she is embarrassed by her credit rating and her history of bill-paying, and is worried that this process will bring her to the attention of collection agencies. Lourdes acknowledges her concerns, and validates her skill in protecting her own interests. Moreover, she 
suggests to Jeannine that she has a right to make her own decisions, reinforcing her belief in her client's right to self-determination in making financial decisions. Lourdes' skills in reflecting her concerns and responding to them in a factual and non-judgmental fashion helps Jeannine to feel more trusting and willing to return to learn more about services available through the center. As trust builds, Lourdes works with Jeannine to find credit card offers with the lowest fees and interest rates, and a credit limit that will reduce her likelihood of experiencing repayment difficulties. Providing accurate information about safe and non-predatory credit opportunities helps to demonstrate concern and strengthens their alliance as Jeannine begins to trust the worker's authenticity and desire to help.

\section{Securing Goal Commitment}

As basic rapport and trust are built, social workers can begin to move toward understanding clients' specific financial strengths and needs, and begin to establish FCAB goals. While the details of a thorough assessment process are beyond our scope, social workers should begin using exploration skills (Northen, 1995) to gather data and assess clients' financial needs in areas such as human capital, earnings, expenses, budgeting, saving, credit rating and use, and investment. Attention should be paid to both strengths and concerns, and clients should be helped to articulate their own financial concerns and goals (Sages, Griesdorn, Gudmunson, \& Archuleta, 2015).

In this phase, the purpose of the social work intervention is to enhance motivation and to secure a commitment to a set of authentic, mutually-constructed FCAB goals. Goalsetting with clients in any endeavor should be an iterative process, one in which client goals and worker input are shared with one another (Egan, 1998; Woods \& Hollis, 1964). However, there are many pitfalls in the process that social workers have referred to as the contracting phase of practice. For example, social workers can assume that they have established mutual goals with clients without having actually secured a commitment to change. This may occur because clients are responding to social desirability pressures from the social worker, agreeing to goals to which they are not committed, or it can occur because social workers simply write intervention plans and contracts without seeking any input from clients. This often occurs when goals are selected in a cookie cutter approach where all clients are assigned the same goals. Too, workers are sometimes rushed to complete work with clients, and close the deal before clients are ready to commit to action plans. Finally, clients may disengage at the goal-setting phase because they may not feel confident about their ability to commit to programmatic requirements. Working with clients to make sure they understand their options, are truly in agreement about goals and objectives, and feel confident that they can meet them, are all central components of any planned change process (Miller \& Rollnick, 2012). The idea of using motivational interviewing and related theories of change for financial interventions has been recommended by earlier scholarship in this area (Despard \& Chowa, 2010; Kerkmann, 1998; Klontz, Horwitz, \& Klontz, 2015).

Motivational interviewing skills can be particularly useful at the goal-setting phase as a technique that can help to increase motivation and to secure an authentic commitment to goals. Helping clients to articulate their own motivations for FCAB, and considering the 
pros and cons of participation could be helpful. Workers should be mindful of 1) setting a contractual agreement only when a client appears ready, 2) reinforcing the client's own motivations and goals, rather than imposing their own goals, and 3) finding ways to help clients boost their confidence in their ability to meet goals (Miller \& Rollnick, 2012). In the next vignette, we present an example of mutually establishing goals in building financial capability.

Case Example: Goal Setting with James. James is a 39-year-old male with a history of drug addiction and incarceration for minor offenses. He has struggled financially much of his adult life, but in the past, was successful as a cosmetologist, specializing in styling hair in the African American community. While he can no longer afford to be in his own salon, he currently works at a retail hair salon earning just above minimum wage plus tips. He is proud of his talent, and he has been referred to an IDA program to save money to start his own business. He would like to save enough to afford to rent space in a salon near his home, but he is concerned about starting out again on his own without savings to help him transition from paid to self-employment.

James has attended his first orientation class for the IDA program, where he learned about the program and the \$500 annual match cap. Participants are encouraged to save $\$ 40$ per month so they may capture all of the available annual match funds. However, he did not return to complete his paperwork to enroll into the program. His social worker contacts him and he states, "You want me to agree to save $\$ 40.00$ a month and not withdraw any money without your permission. I'm just not sure I can save that much every month...what if I have an emergency?" The worker uses empathic listening skills with James, acknowledging his concerns and encouraging him to come in for an additional meeting. During their time together, the worker helps James to express his reasons for wanting to save, which include a desire to "be his own boss," a desire to impress his family that he is achieving goals, and a desire to earn a higher income. He is also encouraged to express his reservations, which include his fearfulness that $\$ 40$ a month is too much for his budget, and his fear that he will not be able to access funds if he needs them. The worker helps him to balance these "pros and cons" of savings, and clarifies his concerns about emergency withdrawals. She also reviews some of his recent past successes and connects those to her belief that he has the capacity to save. After some discussion, James agrees to participate and sets a goal of \$25 per month with the assurance that his deposits can vary if necessary. James and his worker reinforced his commitment by calling his girlfriend during the session to share his saving goals with her and to seek her willingness to help encourage him to save. James has entered into the FCAB process with increased confidence and an authentic commitment to his saving goal. 


\section{Overcoming Obstacles and Developing Financial Strategies}

During what we might refer to as the work phase of FCAB, clients will be engaged in active work to meet the goals they established in the previous stage. Completing job training, repairing credit, opening savings accounts and making deposits, completing and following budget plans - all of these are examples of FCAB opportunities that may be available to clients. As clients begin to participate fully in FCAB programs, some will succeed without encouragement, others will benefit from participation in structured activities such as financial education classes and activities, while others will not participate at all. Helping clients to brainstorm ways to meet their FCAB goals requires creativity and initiative on the part of the social worker, who can help clients to succeed and overcome obstacles. The attainment of financial capability can be enhanced through helping clients to develop financial problem-solving skills and to persevere in the face of setbacks and adversity. A variety of problem-solving skills might be useful for FCAB participants.

Research has indicated that successful savers use a variety of cognitive and behavioral strategies designed to identify and set aside funds for saving (Beverly, Sherraden, \& Schreiner, 2003). While these strategies have not been linked to direct practice, it is notable that the use of cognitive behavioral therapy techniques to increase financial well-being has been suggested previously (Ford, Baptist, \& Archuleta, 2011). Connecting the use of these observed saving strategies with cognitive behavioral practice methods in an intentional way could increase client success in FCAB activities. For example, the use of daily thought records, spending logs, and cognitive restructuring techniques might be helpful in creating behavioral strategies and mental accounting techniques to help build clients' financial problem-solving repertoires (Nabeshima \& Klontz, 2015). Using insights from solutionfocused treatment has also been suggested by Kim and Elliott (2013) as a technique for promoting financial literacy.

During any process of behavioral change, clients inevitably face some setbacks or obstacles to success. Helping clients to continue despite setbacks or adversity is key to any change effort. Providing encouragement, providing verbal affirmation of the difficulty of FCAB, and reframing setbacks or mistakes as part of an ongoing learning process can help clients to continue with their efforts. These are sometimes referred to as affirming skills, the ability to provide support to clients during a difficult verbal interaction or a point in the change process. To support and encourage a client to make positive change is important. When clients stop reaching their goals, social workers may lapse into being judgmental on the one hand, or becoming overly comforting and placating on the other. Acknowledging the setback, reframing it as a normal part of change, and helping the client to consider different behavioral options moving forward are essential steps in providing support. These again are skills and strategies used in the common factors approach to social work intervention (Cameron \& Keenan, 2010).

Case Example: Financial Skill Development with Li Chin. Li Chin is a client of a faith-based social service agency which has recently launched a homeownership IDA program. She has engaged with the agency and her social worker, and has made a commitment to participating in the program, motivated by her desire to raise her two children in a single-family home rather than the apartment they 
currently occupy. Despite her commitment to save for a home, Li Chin has little experience with budgeting and saving, and wishes to learn new skills.

Katrina, a social worker, is leading a savings club for participants in the IDA program. The club holds social events, fundraisers, group meetings, and financial education classes. To help Li Chin and the other clients find new ways to save money, Katrina uses techniques drawn from cognitive behavioral therapy. Each client keeps a daily spending log in which they record expenditures and the degree to which they felt they needed the purchase. Later, the members review their purchases at the savings club meeting and discuss whether purchases are a "want" or a "need." Li Chin has identified several items that she buys weekly that are not necessary, and that could help her save the $\$ 50.00$ per month she has set as a savings goal. Li Chin also has learned some cognitive skills to help her decrease spending, and has created a behavioral plan of writing a check to deposit into the IDA on bill-paying day, thus helping her to cognitively reframe her saving as a debt that she must pay. During the group, Li Chin has shared her strategies with other club members, and has gained some new behavioral and cognitive skills from other's suggestions as well.

\section{Promoting Self-Reflection and Abstract Thinking}

Termination has been referred to as the neglected phase of social work practice (Fox, Nelson, \& Bolman, 1969), but close attention to what happens during endings is important for the ongoing well-being of FCAB participants. As clients end their work in FCAB and reach their financial goals, social workers should engage in termination tasks designed to anchor their gains and help them to plan for future goals. Termination of involvement with the FCAB program should be seen as the beginning point of applying and deepening newly developed financial capabilities. This requires a process of self-reflection on the process of FCAB, and encouragement of the skill of abstraction-applying recently gained skills to new and less familiar financial challenges. Ford and colleagues (2011) acknowledge the need to attend to termination phase issues in financial work with clients.

First, celebrating their accomplishments could be a helpful way to recognize new successes and prompt clients to reflect on their efforts. Engaging in a social ritual, such as a "graduation," can be affirming for a client who has achieved success, and can communicate hope and possibility to other clients still working toward their goals. Particularly with group-based processes (job training classes, etc.), such a process can also provide a chance for clients to terminate their relationships with one another and with the agency, and can help clients to express and resolve feelings they may have about relationships that are ending (Anthony \& Pagano, 1998). Further, a review of the process they have undergone in FCAB can be helpful in reflecting upon what they have accomplished and to consider the nature of the new skills and knowledge they have gained. Such self-reflection can help to anchor their gains, and assist them in thinking abstractly about how their new skills and knowledge could be applied in different financial situations and future goal attainment. In cognitive-behavioral theory, workers often engage in relapse prevention sessions at the end of their work (Marlatt \& Donovan, 2005). Similarly, helping clients to think about the financial circumstances they are likely to face and to consider 
how they might apply their new capabilities could be a helpful intervention at this stage. In this vignette, we consider termination tasks with a young adult client:

Case Example: Termination with Joshua. Joshua is a 22-year-old participating in a youth employment program, earning his GED while gaining skills in the construction trades. The program assists youth in their first employment settings to leverage the experience to begin to develop new financial capabilities. Joshua has completed the two-year program and has secured work in construction, and has completed adult living skills, money management skills, and related classes. Joshua also has his first checking account and debit card, and recently passed his GED exam. During his final meetings with Tonya, his social worker, they review his progress in the program, and recount the "highs and lows" of the experience. She also reminds him of the goals he has accomplished, and they discuss the progress he has made on his goals in job skill acquisition, money management, and bill paying. Tonya helps him to review some of the challenges he may be facing soon, including the new credit card offers he has received. They discuss the capabilities he has developed that he can draw on in future financial transactions, and discuss area resources that he may access as he faces his next financial hurdles, such as getting his own apartment and making major purchases such as furniture or a car. Joshua exits the program feeling proud of what he has achieved, and with a greater ability to apply his new skills to upcoming life transitions.

\section{Evaluating Practice and Disseminating Knowledge}

In the generalist model, the final stage of practice is evaluation of outcomes (KirstAshman \& Hull, 2011). In FCAB practice, the social worker's role should be to evaluate the effectiveness of interventions, and to gather information about client's perceptions of practice interventions, program features, and relevant financial policy. To address the impacts of larger systems of financial opportunity on client well-being, the most feasible course of action for social workers in FCAB settings is to systemically use their knowledge of client experiences to provide feedback to promote effective, safe, and accessible policies and programs. While direct practice workers may not be able to regularly lobby policymakers regarding the regulation of financial products, for example, they can gather data that explores the factors that helps clients to achieve greater financial well-being and those that create barriers to financial capability. Understanding real-world client experiences with banks, credit unions, savings accounts, debit and credit cards, and job training programs allows workers to document financial narratives and then introduce them to other professionals through presentations, trainings, and agency-level advocacy regarding the design of programs. Similarly, FCAB workers could use their practice-based findings to help inform policy briefs and social media campaigns, or to craft legislative testimony. Diffusion of innovations theory (Rogers, 1962) suggests that social change can be the result of the diffusion of ideas, which are taken up at various rates depending upon a variety of factors such as their riskiness, cost, or perceived ability to help solve a problem. Policy scholars have used diffusion of innovations theory to describe the successful dissemination of policy ideas, and have emphasized the importance of policy entrepreneurs who actively work to disseminate policy innovations and to persuade policy-makers to adopt new 
practices (Berry \& Berry, 1999). Grinstein-Weiss, Wagner, and Edwards (2005) have applied this model to the development of Individual Savings Account legislation in various U.S. states, and their work helps to clarify the role of FCAB workers in impacting the environment of financial policies and programs through idea diffusion. In other words, FCAB social workers can work to use their knowledge to inform and shape the actions of policy entrepreneurs working in the fields of financial social work and economic wellbeing.

This process of evaluation and diffusion of best practices is consistent with the principles of evidence-based practice (Proctor, 2004), practice-based research (Dodd \& Epstein, 2012) as well as the Council on Social Work Education's (CSWE, 2015) educational competencies which require social work students to learn to evaluate their practice and inform policy and practice through their findings. Proctor (2004) notes that evaluating and reporting findings related to one's practice is especially important when a practitioner has engaged in an innovation of an empirically established best-practice. In this case example, we explore a social worker's role in using practice-based research data to contribute to the process of improving opportunity structures to make them more accessible and appealing to clients.

Case Example: Miguel's Use of Client Data to Impact Programs and Policy. Miguel is an FCAB provider who is working to launch a new Individual Development Account program. Miguel leads outreach and enrollment activities, and he is working in a rural area that has many immigrants and refugees, including people who are undocumented residents of the U.S. After talking with a potential client named Ana Marie, who declines to work with him, he has noted that many of the people with whom he speaks are hesitant to participate because they believe that they do not have adequate identification to open a savings account. Miguel creates a spreadsheet which documents the number of potential accounts that he is unable to open, and the stated reasons from clients for opting out of involvement in the program. He shares this documented concern with his agency director and works with the agency's program managers to find a list of acceptable documents that can be used at area banks in lieu of a state-issued driver's license. This information is then disseminated throughout his agency and partner agencies, and Miguel shares this knowledge through a statewide listserv group targeted to FCAB providers in his state. Miguel and his co-workers also have learned that some U.S. cities are issuing their own identification cards separate from state I.D.s, and they are planning a meeting with an area city councilperson to propose a similar policy for their own small town. 
Table 1. Stage Specific Skills in a Financial Capability Process Model

\begin{tabular}{|c|c|c|c|}
\hline Stage & Essential Tasks & Related Skills & Theoretical Base \\
\hline $\begin{array}{l}\text { Rapport- } \\
\text { Building and } \\
\text { Engagement }\end{array}$ & $\begin{array}{ll}\text { - } & \text { clarify roles } \\
\text { - } & \text { establish confidentiality } \\
\text { - } & \text { learn about how client } \\
\text { decided to consider FCAB } \\
\text { activities }\end{array}$ & $\begin{array}{l}\text { - } \text { conveying warmth } \\
\text { - demonstrating } \\
\text { authenticity } \\
\text { - use of reflective } \\
\text { listening }\end{array}$ & $\begin{array}{l}\text { - common factors } \\
\text { theory } \\
\text { - } \text { humanistic theory }\end{array}$ \\
\hline $\begin{array}{l}\text { Securing } \\
\text { Financial Goal } \\
\text { Commitment }\end{array}$ & 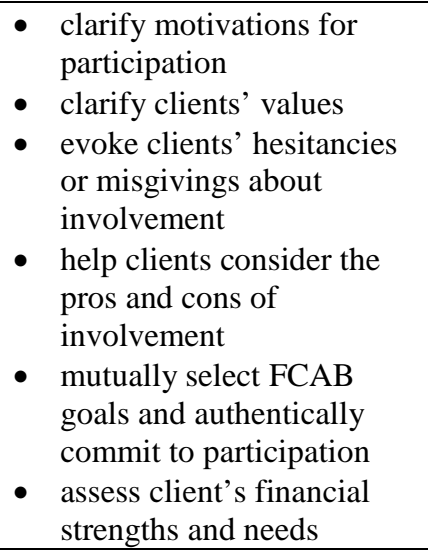 & $\begin{array}{ll}\text { - } & \text { use of reflective } \\
\text { - } & \text { askining evocative } \\
\text { questions } \\
\text { - } \\
\text { assessing readiness } \\
\text { to commit to FCAB } \\
\text { - } \text { psycho-social } \\
\text { assessment skills } \\
\text { - } \text { contracting and } \\
\text { intervention planning } \\
\text { skills } \\
\text { - } \text { strategically offer } \\
\text { suggestions for goals }\end{array}$ & $\begin{array}{ll}\text { - } & \text { motivational } \\
\text { interviewing } \\
\text { - } \\
\text { task-centered } \\
\text { social work } \\
\text { practice }\end{array}$ \\
\hline $\begin{array}{l}\text { Overcoming } \\
\text { Obstacles and } \\
\text { Developing } \\
\text { Financial Skills }\end{array}$ & $\begin{array}{l}\text { - } \text { review progress on agreed } \\
\text { upon goals } \\
\text { - } \text { document and explore } \\
\text { successes and set backs } \\
\text { - } \quad \text { identify cognitive and } \\
\text { behavioral solutions to } \\
\text { problems } \\
\text { - clarify, reinforce, and } \\
\text { anchor cognitive and } \\
\text { behavioral strategies }\end{array}$ & $\begin{array}{ll}\text { - } & \text { exploring, } \\
& \text { elaborating, and } \\
& \text { affirming skills } \\
\text { - } & \text { reframing behaviors } \\
\text { - } & \text { cognitive } \\
\text { interventions } \\
\text { - } \\
\text { behavioral } \\
\text { interventions } \\
\text { - } & \text { solution-focused } \\
\text { interviewing } \\
\end{array}$ & $\begin{array}{ll}\text { - } & \text { cognitive } \\
\text { behavioral therapy } \\
\text { - } & \text { brief solution } \\
\text { focused treatment }\end{array}$ \\
\hline $\begin{array}{l}\text { Encouraging Self } \\
\text { Reflection and } \\
\text { Abstract } \\
\text { Thinking }\end{array}$ & $\begin{array}{ll}\text { - } & \text { review successes and } \\
\text { unmet goals in FCAB } \\
\text { - } \\
\text { reflect on knowledge gains } \\
\text { and behavioral successes } \\
\text { - } \text { frame new skills, } \\
\text { knowledge, and successes } \\
\text { as financial capability } \\
\text { - help clients to think about } \\
\text { and prepare for future }\end{array}$ & $\begin{array}{ll}\text { - } & \text { exploring, } \\
& \text { elaborating skills } \\
\text { - } & \text { summarizing skills } \\
\text { - } & \text { reframing behaviors } \\
\text { - } & \text { relapse prevention } \\
& \text { planning skills }\end{array}$ & 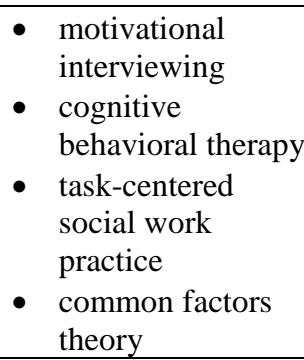 \\
\hline $\begin{array}{l}\text { Evaluation of } \\
\text { Practice and the } \\
\text { Diffusion of } \\
\text { Knowledge }\end{array}$ & $\begin{array}{l}\text { evaluating practice } \\
\text { outcomes quantitatively } \\
\text { and qualitatively } \\
\text { disseminate findings } \\
\text { formally and informally to } \\
\text { practitioners, researchers, } \\
\text { and policy-makers }\end{array}$ & $\begin{array}{l}\text { - } \text { documenting client } \\
\text { perceptions } \\
\text { mining data for } \\
\text { themes and patterns } \\
\text { oral and written } \\
\text { communication skills } \\
\text { appropriate for the } \\
\text { effective expression } \\
\text { of practice research } \\
\text { findings }\end{array}$ & $\begin{array}{l}\text { - diffusion } \\
\text { innovation theory }\end{array}$ \\
\hline
\end{tabular}




\section{Discussion and Conclusion}

In this paper, we have contended that the individual must be considered as a conscious and purposeful actor in the FCAB process. Arguing against both structuralism and methodological individualism, we suggest that the individual is neither the sole determinant of their economic capabilities, nor a passive recipient of structural forces that determine their outcomes. Rather, human beings act within the economic and social context available to them, with varying degrees of success in achieving financial capability. We believe that this transformational practice framework is a needed corrective to the structuralism that has dominated asset-building, and to the individualism that dominates financial counseling practice. What is more, an examination of these ontological underpinnings of financial capability and asset building theory provides us with an opportunity to truly explore the reciprocal nature of human reality and social work's emphasis upon the person-environment configuration.

Our model is based on four assumptions: 1) that psychological and behavioral characteristics matter in the development of financial capability, particularly trust, motivation, commitment, problem-solving skills, perseverance, and self-reflection, 2) that these core psychological characteristics can be consciously promoted by social workers during the FCAB process, 3 ) that the skills and perspectives that drive direct practice in social work generally are applicable to direct practice in FCAB, and 4) successful FCAB practice requires a simultaneous focus on both micro and macro levels of reality. We presented a five-stage model that parallels the stages in generalist social work (KirstAshman \& Hull, 2011), suggesting that the individual determinants of FCAB can be encouraged and fostered through the use of basic interviewing skills and by drawing on insights from models such as motivational interviewing, cognitive behavioral therapy, solution focused work, and diffusion theory. While such perspectives have been suggested before in the literature on financial education, counseling, therapy, and coaching, we argue that what makes the social work perspective distinct is that it maintains the personenvironment perspective throughout. We contend that it is the transactions between individuals and opportunity structures that should be the focus of financial social work. The purpose of such direct practice interventions in FCAB should be on helping clients to modify their behaviors in order to interact with financial opportunity structures in meaningful, conscious, and careful ways, and on shaping programs and policy to provide financial programs that are safe, accessible and effective. Focusing on these transactions and the client characteristics that can promote connections to such structures could be what makes financial social work distinct from those approaches taken by other human service professions.

We recognize, of course, that our work is speculative, and it is a proposed model based more upon theory than on empirical studies. This is to be expected as we are attempting to develop an idea that has been somewhat overlooked in the FCAB field. More work must be conducted in this area, including systematic research using rigorous research designs and measurement. Moreover, we acknowledge that there are significant barriers to such research. The concern that FCAB must be accomplished with minimal staff time due to costs constraints will be a serious and genuine concern. The long-standing debate about 
whether FCAB services should be high touch or low touch will also continue to drive the climate around this topic (Mahon, 2006).

We believe our framework can be a contribution to curricula in social work education. Despite the formal commitment of the CSWE and the National Association of Social Workers (NASW) who profess adherence to the dual roles of social work practice, in the preponderance of schools, the curriculum is primarily clinical in nature (Rothman \& Mizrahi, 2014). While action is needed to strengthen the place of macro practice itself within social work education, it is also necessary to demonstrate to more clinically-oriented social work students and practicing social workers the relevance of clinical theory and practice to issues such as financial functioning and well-being in addition to the common emphasis of clinicians on matters such as social relationships and mental health. From a more clinical standpoint, financial capability work provides the profession of social work an arena in which to bridge a gap between the historical emphasis of asset building work on building institutional structures and opportunities such as Individual Development Accounts (Sherraden, 1991) with a more active micro practitioner role in the financial lives of their low-income clients. CSWE (2017) has begun to address this formally through the creation of their Clearinghouse for Economic Well-Being in Social Work Education.

Opportunities for social workers to engage in FCAB practice may be growing. For example, the Local Initiatives Support Corporation (LISC) in 2004 launched their Financial Opportunity Centers, which employ financial coaches to promote financial well-being (Roder, 2015). They now have 70 such centers across the US, which indicates awareness that direct practice relationships and methods are important in promoting financial capability (Walker \& Huff, 2012). Moreover, the American Academy of Social Work and Social Welfare has identified building financial capability practice methods as part of its Grand Challenges for Social Work Initiative (Sherraden et al., 2015). We feel hopeful that interventions designed to create opportunity structures and foster individual-level behavioral change will continue to grow. Focusing on structures and individuals in tandem is essential if we wish to optimize client financial well-being and capabilities in the years to come. It is exciting to us that the profession of social work, with its attention to both individuals and the environments they inhabit, is well-poised to provide leadership in this important field of practice.

\section{References}

Anthony, S., \& Pagano, G. (1998). The therapeutic potential for growth during the termination process. Clinical Social Work Journal, 26(3), 281-296. doi: https://doi.org/10.1023/A:1022872011238

Archuleta, K. L., \& Grable, J. E. (2011). The future of financial planning and counseling: An introduction to financial therapy. In J. E. Grabel, K. L., Archuleta, \& R. R. Nazarinia (Eds.), Financial planning and counseling scales (pp. 33-59). New York: Springer.

Berry, F., \& Berry, W. (1999). Innovation and diffusion models in policy research. In Paul Sabatier (Ed.), Theories of the policy process (pp. 169-200). Boulder, CO: Westview Press. 
Beverly, S., \& Sherraden, M. (1999). Institutional determinants of saving: Implications for low-income households and public policy. Journal of Socio-Economics, 28, 457473. doi: https://doi.org/10.1016/S1053-5357(99)00046-3

Beverly, S., Sherraden, M., \& Schreiner, M. (2003). A framework of asset accumulation stages and strategies. Journal of Family and Economic Issues, 24(2), 143-156. doi: https://doi.org/10.1023/A:1023662823816

Beverly, S., Sherraden, M., Zahn, M., Williams Shanks, T., Nam, Y., \& Cramer, R. (2008). Determinants of asset-building. Washington, DC: Urban Institute.

Bhaskar, R. (1975). A realist theory of science. Hassock Sussex: Harvester Press.

Birkenmaier, J., Sherraden, M., \& Curley, J. (2013). Financial capability \& asset development: Research, education, policy and practice. UK: Oxford University Press. doi: https://doi.org/10.1093/acprof:oso/9780199755950.001.0001

Blaikie, N. (1993). Approaches to social enquiry. Cambridge, UK: Polity Press.

Blau, P.M. (1977). A macrosociological theory of social structure. American Journal of Sociology, 83(1), 26-54. doi: https://doi.org/10.1086/226505

Bourdieu, P. (1980). The logic of practice. Oxford: Polity Press.

Cameron, M., \& Keenan, E. (2010). The common factors model: Implications for transtheoretical clinical social work practice. Social Work, 55(1), 63-73. doi: https://doi.org/10.1093/sw/55.1.63

Collins, M. J., \& Birkenmaier, J. M. (2013). Building the capacity of social workers to enhance financial capability. In J. M. Birkenmaier, M. Sherraden, \& J. Curley’s (Eds.), Financial capability and asset development: Research, education, policy, and practice (pp. 302-322). New York: Oxford University Press.

Collins, J. M., \& O’Rourke, C. (2009). Financial education and counseling: Still holding promise. Journal of Consumer Affairs, 44(3), 483-498. doi: https://doi.org/10.1111/j.1745-6606.2010.01179.x

Council on Social Work Education. (2015). Education policy and accreditation standards for baccalaureate and master's programs in social work. Alexandria, VA: Author.

Council on Social Work Education. (2017). Clearing house for economic well-being in social work education. Alexandria, VA: Author. Retrieved November 19, 2017 from http://www.cswe.org/Centers-Initiatives/Initiatives/Clearinghouse-for-EconomicWell-Being.aspx

Despard, M., \& Chowa, G. (2010). Social workers' interest in building financial capability. Journal of Financial Therapy, 1(1), 23-41. doi: https://doi.org/10.4148/jft.v1i1.257

Dodd, S.-J., \& Epstein, I. (2012). Practice-based research in social work: A guide for reluctant researchers. London: Routledge 
Egan, G. (1998). The skilled helper: A problem-management approach to helping. Belmont, CA: Brooks/Cole.

Ehrenreich, J. (1985). The altruistic imagination: A history of social work and social policy in the United States. Ithaca, NY: Cornell University Press.

Ford, M., Baptist, J., \& Archuleta, K. (2011). A theoretical approach to financial therapy: The development of the Ford Financial Empowerment Model. Journal of Financial Therapy, 2(2), 20-40. doi: https://doi.org/10.4148/jft.v2i2.1447

Fox, E., Nelson, M., \& Bolman, W. (1969). The termination process: A neglected dimension in social work. Social Work, 14(4), 53-63.

Germaine, C., \& Gitterman, A. (1980). The life model of social work practice: Advances in theory and practice. New York: Columbia University Press.

Giddens, A. (1984). The constitution of society: Outline of a theory of structuration. Oxford: Polity Press.

Grinstein-Weiss, M., Wagner, K., \& Edwards, K. (2005). Diffusion of policy innovation: The case of Individual Development Accounts as an asset-building policy (CSD Working Paper 05-08). St. Louis, MO: Washington University, Center for Social Development.

Johnson, E., \& Sherraden, M.S. (2007). From financial literacy to financial capability among youth. Journal of Sociology and Social Welfare, 34(3), 119-145.

Kemp, S. Whittaker, J., \& Tracy, E. (1997). Person-environment practice: The social ecology of interpersonal helping. New York: Aldine DeGruyter.

Kerkmann, B. (1998). Motivation and stages of change in financial counseling: An application of a transtheoretical model from counseling psychology. Financial Counseling and Planning, 9(1), 13-20.

Kim, J., \& Elliott, W. (2013). The role of identity motivational based and solution focused brief therapy in unifying accounts and financial education in school-related CDA programs. Children and Youth Services Review, 45, 402-410.

Kirst-Ashman, K., \& Hull, G. (2011). Understanding generalist practice. Belmont, CA: Brooks/Cole.

Kjosavic, D. (2003). Methodological individualism and rational choice theory in neoclassical economics: A review of institutionalism. Forum for Development Studies, 80 (3), 202-245.

Klontz, B., Horwitz, E., \& Klontz, P. (2015). Stages of change and motivational interviewing in financial therapy. In B. Klontz, S. Britt, \& K. Archuleta (Eds.), Financial therapy: Theory, research, and practice (pp. 347-362). New York: Springer. doi: https://doi.org/10.1007/978-3-319-08269-1_20 
Mahon, C. (2006). Achieving scale in asset building programs: Operational challenges and opportunities in Individual Development Accounts. Washington, DC: The Aspen Institute.

Marlatt, G. A., \& Donovan, D. (2005). Relapse prevention: Maintenance strategies in the treatment of addictive behaviors. New York: Guilford Press.

Meyer, C. (1983). Clinical social work in the ecosystem perspective. New York: Columbia University Press.

Miller, W., \& Rollnick, S. (2012). Motivational interviewing: Preparing people to change addictive behavior. New York: Guilford Press.

Nabeshima, G., \& Klontz, B. (2015). Cognitive-behavioral financial therapy. In B. Klontz, S. Britt, \& K. Archuleta (Eds.), Financial therapy: Theory, research, and practice (pp. 143-160). New York: Springer. doi: https://doi.org/10.1007/978-3-319$\underline{08269-1 \_9}$

Northen, H. (1995). Clinical social work knowledge and skills. New York: Columbia University Press.

Olen, H. (2012). Pound foolish: Exposing the dark side of the personal finance industry. New York: Portfolio.

Payne, M. (2011). Humanistic social work: Core principles in practice. Oxford, UK: Oxford University Press.

Proctor, E. (2004). Leverage points for the implementation of evidence-based practice. Brief Treatment and Crisis Intervention, 4(3), 227-242. doi: https://doi.org/10.1093/brief-treatment/mhh020

Roder, A. (2015). Building stronger financial futures: Interim findings from the evaluation of LISC's Financial Opportunity Centers. New York: Economic Mobility Corporation.

Rogers, C. (1961). On becoming a person: A therapist's view of psychotherapy. London: Constable Press.

Rogers, E. (1962). Diffusion of innovations. New York: Free Press of Glencoe.

Rollnick, S., Miller, W., \& Butler, C. (2008). Motivational interviewing in health care: Helping patients change behavior. New York: Guilford Press.

Rothman, J., \& Mizrahi, T. (2014). Balancing micro and macro practice: A challenge for social work. Social Work, 59(1), 91-93. doi: https://doi.org/10.1093/sw/swt067

Sages, R., Griesdorn, T., Gudmunson, C., \& Archuleta, K. (2015). Assessment in financial therapy. In B. Klontz, S. Britt, \& K. Archuleta (Eds.), Financial therapy: Theory, research, and practice (pp. 69-85). New York: Springer. doi: https://doi.org/10.1007/978-3-319-08269-1_5

Scanlon, E., \& Wittman, L. (2010). From Helena to Harlem: Experiences of lowerincome urban and rural parents in children's savings account programs (CSD 
Working Paper 10-38). St. Louis, MO: Washington University, Center for Social Development.

Shanks, T., Nicoll, K., \& Johnson, T. (2014). African-Americans and assets: Attempting to capitalize on hopes for children through College Savings Accounts. Review of Black Political Economy, 41, 3, 337-356. doi: https://doi.org/10.1007/s12114-0149185-y

Sherraden, M., Laux, S., \& Kaufman, C. (2007). Financial education for social workers. Journal of Community Practice, 15(3), 9-36. doi:

https://doi.org/10.1300/J125v15n03_02

Sherraden, M. (1991). Assets and the poor: A new American welfare policy. Armonk, NY: M.E. Sharpe.

Sherraden, M., Huang, J., Frey, J., Birkenmaier, J., Callahan, C., Clancy, M., \& Sherraden, M. (2015). Financial capability and asset building for all (Grand Challenges for Social Work Initiative, Working Paper No. 13). Cleveland, OH: American Academy of Social Work and Social Welfare.

Walker, C., \& Huff, D. (2012). Expanding financial opportunity: LISC's experience with scaling up Financial Opportunity Centers. Retrieved January 16, 2015 from http://community-wealth.org/content/expanding-financial-opportunity-lisc-sexperience-scaling-financial-opportunity-centers

Woods, M., \& Hollis, F. (1964). Casework: A psychosocial therapy. New York: Random House.

Zahle, J., \& Collin, F. (2014). Rethinking the individualism-holism debate: Essays in the philosophy of social science. London: Springer. doi: https://doi.org/10.1007/978-3319-05344-8

Author note: Address correspondence to: Edward Scanlon, PhD, School of Social Welfare, University of Kansas, Twente Hall, Lawrence, KS 66045. escanlon@ku.edu 